\title{
REDESAIN PARADIGMA PENDIDIKAN ISLAM TOLERAN DAN PLURALIS DI PONDOK PESANTREN \\ (Studi Konstruktivisme Sikap Kiai dan Sistem Nilai di Pondok Pesantren Nurul Jadid, Paiton, Probolinggo)
}

\author{
S. Mahmudah Noorhayati \\ (Institut Agama Islam Sahid Bogor) \\ noorhayatimahmudah@gmail.com
}

\begin{abstract}
:
Sebagaimana telah jamak diketahui bahwa salah satu bagian dari pesantren adalah nilai-nilai atau sikap pendirian dari seorang kiai yang sangat dominan dalam membentuk identitas santrinya. Nilai-nilai tersebut tidaklah cukup disampaikan secara jalur penyampaian pengajaran lisan, tetapi juga harus diaktualisasikan, didesain ulang, dan diimplementasikan dalam ruang proses yang lebih luas. Artikel ini membahas tentang pencapaian dibalik penanaman nilai, pemodelan dan indoktrinasi dalam pesantren, utamanya dalam hal pendirian kiai dalam sikap toleransi dan keberagaman budaya. Pondok Pesantren Nurul Jadid menjadi subjek dalam penelitian ini. Dengan menggunakan pendekatan fenomenologi di lapangan, data yang didapatkan dianalisa dalam bingkai kerja teori konstruktivisme Peter L. Berger. Hasil penelitian ini menunjukkan bahwa Pondok Pesantren Nurul Jadid membangun nilai-nilai toleransi dan penghargaan keberagaman budaya melalui pandangan sufisme dan disampaikan melalui pemodelan pandangan kiai dalam aktifitas sehari-hari dan kejadian-kejadian yang tidak direncanakan.
\end{abstract}

Kata Kunci: Pendidikan Toleransi; Pesantren; Budaya Damai; 


\begin{abstract}
:
It is the fact that one of ubiquitous element of pesantren is kiai's dominant values or stance in developing santri's identity. Those values is not enough merely delivered in oral transmission, but those have to be actualized, redesigned, and reimplemented in wider social contexts. This article deals with the achievement beyond the cultivation of values, modelling, and indoctrination inside pesantren, specifically in terms of kiai's stances towards tolerance and multiculturalism. Pondok Pesantren Nurul Jadid becomes the subject of this research. Approached by phenomenological field work, collected data is analized within Peter L. Berger constructivism framework. This study shows that Pondok Pesantren Nurul Jadid constructs values of tolerance and multiculturalism through sufism views which is delivered through modelling by kiai in daily routines and accidental cases.
\end{abstract}

\title{
Keyword: Tolerance Education; Pesantren; Peace Culture;
}

\section{A. Pendahuluan}

Siapapun tak dapat menyangkal, jika sejarah Indonesia hari ini, kembali pada kontestasi mencari islamisme (sikap berislam) yang ideal di ruang demokrasi. Padahal, kontestasi seperti itu, sudah menjadi diskursus panjang dari Indonesia lahir, hingga proses demokratisasi (baca; reformasi) diberlakukan di negeri ini. Pada periode awal misalnya, para penyeru demokratisasi mengajukan diskursus Islam yang toleran, pluralis, moderat, dan inklusif, sebagai jalan keluar dari kanalisasi sikap keislaman yang dilakukan di era Soeharto. Konon, dalam pandangan mereka, sikap-sikap keislaman tersebut, merupakan bagian terpenting dari identitas keislaman yang dimiliki oleh umat Islam di Indonesia. Mereka, acapkali, menyerukan bahwa Islam-Indonesia tidak dibangun melalui jalur dan paradigma peperangan. Islam-Indonesia tidak dibentuk dari cara pemaksaan. Dan, Islam-Indonesia hadir berasal dari sikap asimilatif sekaligus ramah terhadap kekayaan budaya lokal yang ada. Meminjam istilah Abdurrahman Wahid (Gus Dur), Islam Indonesia terbentuk dari pribumiisasi nilai-nilai keislaman, bukan islamisasi pribumi. ${ }^{1}$

Oleh karena kembali pada kontestasi Islamisme lagi, maka hari ini, pengembalian ingatan masyarakat terhadap identitas asli Islam-Indonesia menjadi sangat penting. Terlepas dari adanya keberpihakan politik elit atau tidak dalam konteks ini. Penulis beranggapan, salah satu cara yang efektif adalah

\footnotetext{
1 Abdurrahman Wahid, "Pesantren Sebagai Sub-Culture Pendidikan di Indonesia" dalam M. Dawam Rahardjo (ed), Pergulatan Dunia Pesantren, Membangun dari Bawah (Jakarta: P3M, 1985), 4.
}

Jurnal Pendidikan Agama Islam (Journal of Islamic Education Studies)

Volume 5 Nomor 1 (2017)

ISSN(p) 2089-1946\& ISSN(e) 2527-4511

Hal. 2 - 20 
melalui institusi pendidikan Islam otentik yang lahir dari Indonesia, bernama Pondok Pesantren. Para sejarawan menyebut, pondok pesantren - selain sebagai lembaga transmisi ilmu keislaman - juga merupakan lembaga dakwah keislaman khas Indonesia. ${ }^{2}$ Pesantren adalah produk budaya Indonesia dalam konteks lembaga pendidikan. ${ }^{3}$ Pun pesantren memiliki nilai lebih, karena menjadi bagian dari perjuangan mendirikan Indonesia dari penjajahan kolonial Belanda dan sekutu. Bagi penulis, pesantren adalah identitas ideologis bangsa dan masyarakat Indonesia yang plural. Pesantren, menurut Azyumardi Azra, memiliki sikap adaptif dan asimilatif yang sangat kuat terhadap perubahan di masyarakat, serta memiliki kemampun bertahan yang tidak dapat ditiru oleh lembaga pendidikan lainnya. ${ }^{4}$

Namun problemnya, cara baca akan peran kuat pondok pesantren membentuk Islam-Indonesia, juga diprioritaskan oleh kelompok-kelompok radikal dan trans-nasional. 5 Dampaknya, keberadaan pondok pesantren tidak lagi identitk dengan Indonesia dan basis kepercayaan serta partisipasi kuat masyarakat. Pondok pesantren hari ini, dalam pandangan Halim Soebahar, sudah dirasuki, dicatut, dan diduplikasi oleh kelompok tersebut. ${ }^{6}$ Tidak sekedar itu, harus pula diakui, strategi marketting kelompok-kelompok baru ini lebih efektif daripada strategi yang dibentuk oleh para pendiri pondok pesantren. Branding islamisme murni (baca; langsung dari sumber asal Islam) menjadi daya pembeda

${ }^{2}$ Abdurrahman Mas'ud, Memahami Agama Damai Dunia Pesantren, dalam Badrus Sholeh (Ed), Budaya Damai Komunitas Pesantren (Jakarta: LP3ES, 2007), xvii.

${ }^{3}$ Nurcholish Madjid, Bilik-Bilik Pesantren (Jakarta: Dian Rakyat-Paramadina, tt), 93.

${ }^{4}$ Azzumardi Azra, Pendidikan Islam; Tradisi dan Modernisasi di Tengah Tantangan Millenium III (Jakarta: UIN Jakarta Press, 2012), 79-91.

${ }^{5}$ Sebagaimana diketahui asumsi schooling Islam, Islamic Social Movenment, dan Madrasah and Transnational Linked menjadi topik kajian para indonesianis seperti, Martin Van Bruinessen, Robert W. Hefner, Greg Fealy, dan beberapa ilmua lainnya. Mereka mengasumsikan bahwa ada hubungan sistem pendidikan Islam di Indonesia dan kepentingan global yang sangat kuat. Apakah itu melalui sisi konten, ideologisasi, hingga pendanaan. Dalam pandangan peneliti, asumsi mereka bisa dikongklusikan bahwa, demokratisasi di Indonesia dirasuki oleh kepentingan global yang sangat kuat. Termasuk di dalamnya kepentingan kelompok islamis radikal-transnasional, melalui lembaga pendidikan (dropping Trans-nationalIdeology inside Islamic Institution and Teaching Learning Process). Lihat; Robert W. Hefner, "Islamic School, Sosial Movement, and Democracy in Indonesia", dalam Robert W. Hefner edit, Making Modern islam Politic of Education in South Asia (USA: Hawai University Press, 2009), 58. Lihat juga, Martin Van Bruisennen, "Tradisional and Islamist Pesantrens in Contemporary Indonesia" dalam Fasrish A Noor ed. Madrasa in Asia; Political Activism and Transnational Linkages (Amsterdam; Amsterdam University Press, 2008). 217-218. Bandingkan dengan Greg Fealy dan Bubablo, Jejak Kafilah, terj Akh. Muzaki (Bandung; Mizan, 2001), 94.

6 Abdul Halim Soebahar, Kebijakan Pendidikan Islam dan Poblematika Kekinian. Makalah Stadium General Program S3 IAIN Jember 2017. (Unpublised-Paper). 
dari keberadaan pondok pesantren tradisional yang memiliki keyakinan akan pentingnya perpaduan antara nilai kemasyarakatan dan keislaman yang menjadi fondasi sikap umat Islam di Indonesia.

Tak ayal, dampak 'pencatutan' nama pesantren menjadi basis kelompok radikal, menjadikan wajah Islam-Indonesia buram. J. Esposito misalnya, mengutip para pemikir dan politisi Barat, yang secara terang-terangan menganggap bahwa pesantren (islamic institution) sebagai sarang (camp) dari proses indoktrinasi paham radikal di beberapa negara Islam. ${ }^{7}$ Demikian halnya Charlene Tan, paradigmanya sama. Dia menganalisa kondisi pesantren Ngruki, Solo. Kendati Charlene Tan juga memberikan label smiling institution untuk pesantren Tebuireng. ${ }^{8} \mathrm{Hal}$ ini menandakan bahwa hari ini, umat Islam-Indonesia membutuhkan cara pengembalian konsep dan identitas kepesantrenan yang otentik. Pesantren yang tidak mengajarkan nilai-nilai radikal dan menjadi lawan dari sistem demokrasi yang dijalankan di Indonesia, melainkan pesantren yang bisa menjadi penyangga demokrasi.

Oleh sebab itulah, tulisan ini akan berusaha dan berupaya membangun postulasi nilai-nilai toleransi serta pluralitas yang ada di pondok pesantren, melalui dua pendekatan; pertama, berasal dari kerangkan fenomenologisme (baca; struktur kesadaran Kyai pesantren terhadap nilai tersebut). Kedua, konstruktivisme (baca; pola internalisasi, eksternalisasi dan objektivasi) terhadap para santri yang ada di lingkungan pondok pesantren. Tentu, sebagaimana judul di atas, kajian ini berbentuk studi kasus di Pondok Pesantren Nurul Jadid, Paiton Probolinggo. ${ }^{9}$ Yang kemudian, akan dilakukan proses

7 Termasuk di dalamnya adalah sangkalan Wakil Presiden RI, Moh. Jusuf Kalla, terhadap asumsi bahwa pesantren sebagai sarang terorisme di Indonesia. Lihat; J. Esposito, The Future Of Islam (New York: Routledge, 2003), 2.

8 Charlene Tan, Islamic Education and Indoctrination; The Cases In Indonesia (New York, Routledge, 2011), 137.

9 Pondok Pesantren Nurul Jadid adalah salah satu pesantren yang terletak di Kab. Probolinggo. Pondok Pesantren ini didirikan oleh KH. Zaini Mun'im atas seruan dari beberapa gurunya. Sebagaimana penjelasan pengasuh. Keberadaan PP. Nurul Jadid, selain sebagai lembaga pendidikan Islam, juga merupakan alat politik untuk menjaga keutuhan NKRI dari penjajahan Belanda. Pesantren ini berdiri pada 1 Januari $1949 \mathrm{M}$, dua tahun setelah Indonesia merdeka dan mengalami penjajahan ulang dari sekutu. Visi Pondok Pesantren Nurul Jadid Paiton Probolinggo adalah terbentuknya manusia yang beriman, bertaqwa, berakhlaq al karimag, berilmu, berwawasan luas, berpandangan kedepan, cakap, terampil, mandiri, kreatif, memiliki etos kerja, toleransi, bertanggungjawab kemasyarakatan, serta berguna bagi agama, bangsa dan negara. Trilogi Santri : 1) Berkomitmen pada kewajiban Fardlu 'ain, 2) Berkomitmen dalam meninggalkan dosa-dosa besar, dan 3) Berakhlaq mulya pada Allah dan Makhluq-Nya. Panca Kesadaran Santri : 1) Kesadaran Beragama, 2) Kesadaran Berilmu, 3) Kesadaran Bermasyarakat, 4) Kesadaran Berbangsa dan Bernegara,

Jurnal Pendidikan Agama Islam (Journal of Islamic Education Studies)

Volume 5 Nomor 1 (2017)

ISSN(p) 2089-1946\& ISSN(e) 2527-4511

Hal. 4 - 20 
generalisasi konsep (coding-concept), agar bisa dilaksanakan di beberapa pesantren lainnya. Kajian ini, dalam pandangan penulis, setidaknya memiliki tiga kemanfaatan; pertama, dapat mengembalikan ingatan masyarakat akan nilainilai kepesantrenan yang azali. Kedua, menjadi counter-discourses terhadap cara pandang Barat yang mulai mengidentikkan pesantren dengan gerakan intoleransi di Indonesia. Ketiga, dapat menjadi sumber data untuk mendesain sistem pendidikan Islam yang sesuai dengan nalar berfikir keislaman di Indonesia.

\section{B. Pendidikan Pesantren, Budaya Damai, dan Problem Kekinian}

Para antropolog pesantren menyebut, keberadaan pesantren di bumi nusantara tidak bisa dilepaskan dari peran serta para penyebar Islam, seperti wali songo, dan kepemimpinan generik kiai pesantren di masa-masa awal. Para sejarawan pun mencatat, cara dakwah para penyebar Islam di Indonesia tidak sama dengan infusi Islam di negara lain, yang cenderung menggunakan pendekatan penaklukan dan dominasi sosial-ekonomi kemasyarakatan. Islam hadir ke Indonesia melalui cara-cara yang elegan dan menghargai kepercayaan masyarakat Indonesia di era Nusantara. ${ }^{10}$ Tidak sekedar dalam proses penyebaran dan transmisi ajaran, para wali juga tidak serta-merta menanggalkan institusi dan ritus masyarakat yang bertentangan dengan Islam. Termasuk di dalamnya ialah pondok pesantren. Hanun Asrohah, mengatakan bahwa pondok pesantren merupakan bahasa sangsekerta dan bermuara dari tradisi masyarakat Hindu-Budha dalam sistem pendidikannya. ${ }^{11}$ Kendati adapula pakar yang menyebut, pondok pesantren berasal dari bahasa dan tradisi Arab. ${ }^{12}$

$$
\text { Terlepas dari perdebatan tentang asal-muasal }
$$

kebudayaan/peradaban pondok pesantren. Topik yang lebih urgen adalah, membicarakan tentang bagaimana konstuksi pemahaman yang dibingkai melalui pondok pesantren. Fuaduddin TM mengatakan bahwa pondok pesantren merupakan institusi yang dapat menjadi perekayasa (futurologis) kehidupan

5) Kesadaran Berorganisasi. (lihat Panduan Wali Santri Pondok Pesantren Nurul Jadid Paiton Probolinggo).

10 Menurut Gus Dur, ada tiga elemen yang mampu membentuk Pondok Pesantren sebagai subkultur yaitu; pertama, Pola kepemimpinan yang mandiri tidak terkooptasi oleh Negara; kedua, kitab-kitab yang dijadikan referensi adalah kitab-kitab klasik; ketiga, Sistem nilai yang digunakan adalah bagian dari masyarakat luas. Lihat KH. Abdurrahman Wahid, Pondok Pesantren Masa depan, dalam Said Agil Siraj at all, Pesantren Masa Depan Wacana Pemberdayaan dan Transformasi Pesantren (Bandung: Pustaka Hidayah, 1999), 13-14.

11 Hanun Asrohah, Transformasi Pesantren Pelembagaan Adaptasi, dan Respon Pesantren Dalam Menghadapi Perubahan Sosial (Jakarta: Dwiputra Pustaka Jaya, 2013), 107-108.

12 Ibid., 109. 
berbangsa dan bernegara di dalam konteks masyarakat yang religuous-pluralis. Dia menambahkan, pondok pesantren memiliki tradisi intelektual yang kuat, untuk membentuk gagasan-gagasan ideal kehidupan masyarakat. Selain itu, pesantren memiliki legitimasi sosial dan kultural, melalui kharisma serta ketokohan kyai di dalam masyarakat pesantren dan umum. ${ }^{13}$ Pandangan ini membuktikan bahwa, ada potensi pondok pesantren sebagai inkubator pemahaman keislaman yang pantas dijalankan di Indonesia, yang plural dan multikultural, sekaligus menjadi lembaga legitimasi keislaman, sesuai dengan perilaku yang ditunjukkan dan disampaikan oleh para Kyai kepada masyarakat sekitar.

Untuk lebih menguatkan pandangan tersebut, postulasi yang mereka bangun adala dengan cara mengaitkan sistem budaya pondok pesantren dengan konstruksi kehidupan keberagamaan di Indonesia. Pada bagian ini, menurut perspektif penulis, terkategori menjadi beberapa hal penting; pertama, culturalbrooker dan basis budaya islami-sufistik di dalam pondok pesantren. Kedua, rasa kepemilikan yang tinggi terhadap kebudayaan asili Indonesia. Ketiga, pengembangan dan pembangunan budaya belajar di dalam pondok pesantren. Pada bagian pertama, diakui atau tidak, pesantren memiliki kerangka kebudayaan yang unik, berbeda dengan institusi pendidikan lainnya. Mukti Ali misalnya, dengan sedikit apologetik mengatakan, bahwa pondok pesantren bukanlah lembaga dakwah, bukan lembaga pemberdayaan masyarakat, bukan lembaga ekonomi masyarakat, pesantren bagi Mukti Ali, adalah lembaga reproduksi masyarakat yang memiliki sistem nilai kebudayaan, gotong royong, ketaatan kepada kyai, dan kedisiplinan tinggi, serta memiliki pemahaman keagamaan yang khas dan mendalam. ${ }^{14}$

Anggapan seperti di atas, hadir karena melihat betapa beragamnya konsepsi tentang pondok pesantren, sekaligus kuatnya peran serta pesantren dalam menghadirkan model-model kebudayaan yang baru di tengah masyarakat. Pesantren, pada satu sisi, memang lembaga pendidikan. Namun demikian, keterikatan antara wali santri dan pondok pesantren, bisa berwujud dalam konsepsi patron dan klien. Artinya, keberadaan pondok pesantren tidak bisa dilepaskan dalam peran serta membangun kebudayaan masyarakat yang ada di Indonesia. Selain itu, di dalam pondok pesantren sendiri terdapat carapandang yang beragam terkait corak keislaman. Pada umumnya, para peneliti

13 Fuaduddin TM, "Diversifikasi Pendidikan Pesantren : Tantangan dan Solusi", dalam Jurnal Penelitian Pendidikan Agama dan Keagamaan, Volume 5 Nomor 4, Oktober - Desember 2007, 31-33.

14 Sebagaimana dalam Imam Bawani, Tradisionalisme dalam Pendidikan Islam (Surabaya: Al Ikhlas, 1993), 90.

Jurnal Pendidikan Agama Islam (Journal of Islamic Education Studies)

Volume 5 Nomor 1 (2017)

ISSN(p) 2089-1946\& ISSN(e) 2527-4511

Hal. 6 - 20 
mengkategorikan akar budaya pesantren ada pada sisi sufistik. Maknya, sublimasi karakteristik kehidupan para sufi sangat kental di pondok pesantren. Hal ini, secara antropologis, bisa dilihat dari kitab yang dikaji (kitab kuning karya ulama' salaf) dan pola hidup yang cenderung lebih mementingkan kehidupan akhirat dibandingkan duniawi.

Pada bagian kedua, adanya kesadaran rasa nasionalisme Indonesia. Anggapan ini penulis rangkai dan rangkum berasaskan pada postulasi; pertama, pondok pesantren merupakan alat ulama' untuk melakukan perlawanan terhadap kolonialisme Belanda dan Jepang, di masa-masa perjuangan kemerdekaan. Kedua, para Kyai pesantren, sedikitnya yang bernaung dibawah Nahdlatul Ulama', menerima Pancasila sebagai ideology bangsa untuk dapat menjaga keutuhan Negara Kesatuan Republik Indonesia (NKRI). Kendati pada era-era Orde Baru keberadaan pondok pesantren tidak mendapatkan tempat special dari rezim kekuasaan Soeharto. Ketiga, anggapan Ali Machsan Moesa yang menyebutkan bahwa para kyai - yang bahkan corak keislamannya dipengaruhi oleh paradigm Timur Tengah - tidak memaksakan kehendaknya untuk membangun ideology baru dan carapandang baru keislaman di Indonesia. ${ }^{15}$ Jadi, tidak salah apabila hari ini ada yang berucap "jangan pernah ajari Pondok Pesantren tentang Nasionalisme". Karena, keberadaan pondok pesantren merupakan bagian integral untuk membangun Indonesia yang beragam, melalui nilai-nilai subtantif keislaman.

Terakhir, sistem pembudayaan nilai kepesantrenan, melalui pembelajaran. Sama seperti di atas, para pengkaji pesantren dibuat kebingungan terkait sistem belajar pesantren. Namun yang pasti, Dawam Rahardjo mengatakan bahwa kelebihan daripada sistem pendidikan pesantren ada pada proses yang terasrama dan terlimitasi pengaruh lingkungan eksternal.16 Kelebihan ini, bisa jadi, tidak dimiliki oleh lembaga pendidikan lainnya. Secara teori, terdapat tiga sistem tradisional pembelajaran pesantren; sorogan-wetonan, bandongan dan halaqah. Semua sistem ini muaranya ada pada kyai, kitab kuning dan kemandirian santri untuk melakukan diskusi bersama di dalam lingkungan pondok pesantren. Tapi, dalam perkembangannya, pondok pesantren mulai mensistematisasikan melalui pola integrasi-pendidikan umum atau cara pandang modern di dalamnya. Ada yang menintegrasikan secara selektif; hanya mengambil sistem klasikal/madrasiyah saja, ada pula yang memadukan secara penuh, sehingga sekolah umum didirikan di lingkungan pondok pesantren.

Betapapun, proses pembelajaran - dari sekian banyak dimensi sistem yang ditawarkan di pondok pesantren - fondasi keilmuan pondok pesantren

15 Ali Machsan Moesa, Nasionalisme Kiai (Yogjakarta; LKiS, 2005), 12.

16 Dawam Rahardjo, Pesantren dan Pembaharuan (Jakarta: LP3ES, 1985), 11. 
sangatlah sederhana. Holilurrahman, dalam laporan penelitiannya mengatakan bahwa, cara pondok pesantren mentransformasi keilmuan sebagaimana tertera dalam bingkai berikut ini:

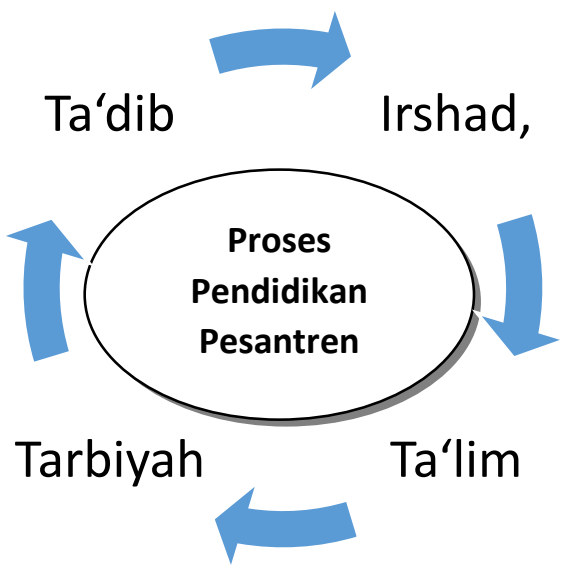

Bagan di atas, menunjukkan bahwa pendidikan pesantren tidak sekedar melalukan proses pembelajaran pengetahuan saja. Melainkan juga proses pemberian contoh melalui bimbingan-bimbingan spiritualis (irshad). Holilurrahman menambah-kan, sistem pembelajaran pondok pesantren, dari sisi desain prosesnya, berorientasi pada pembentukan karakter personal, bukan pada basis penguatan ilmu pengetahuan semata. Hal ini berbeda daripada penggagas islamisasi Ilmu Pengetahuan, yang mendahulukan desain pengetahuan dibandingkan menterjemahkan ilmu agama menjadi perilaku keseharian. Meminjam istilah KH. Hasyim Muzadi, ilmu pengetahuan di pondok pesantren berasal dari kerangka berfikir ngelmoni amal dan ngamalno ilmu (memberi dasar terhadap tindakan-tindakan yang dibudayakan di pondok pesantren, sekaligus mengamalkan ilmu pengetahuan yang sudah didapatkan di pondok pesantren). ${ }^{17}$

Dari beberapa paparan data di atas, dapat disimpulkan, bahwa pondok pesantren merupakan sistem kependidikan Islam yang sangat memahami karakteristik dan nilai kebudayaan yang dianut oleh masyarakat Indonesia. Pondok pesantren tidak akan pernah berkeinginan untuk merubah ideologi Pancasila, NKRI, dan sikap-sikap cinta pada tanah air. Pondok pesantren, sangat memahami model keislaman yang dibutuhkan oleh Indonesia. Karena, para pendiri pondok pesantren ikut serta untuk membangun Indonesia yang plural dan toleran terhadap perbedaan pandangan di dalam masyarakat. Pondok pesantren - kata Mukti Ali - memiliki sikap gotong royong dan persahabatan

17 Holilurrahman, "Reintegrasi Ilmu, Agama, Agen, dan Fondasi Pendidikan Islam (Telaah Pemikiran KH. Hasyim Muzadi)" dalam Jurnal Kependidikan Islam Vol 1 Edisi 3, 171-172.

Jurnal Pendidikan Agama Islam (Journal of Islamic Education Studies)

Volume 5 Nomor 1 (2017)

ISSN(p) 2089-1946\& ISSN(e) 2527-4511

Hal. 8 - 20 
yang kuat diantara satu santri dengan satri lainnya. Mereka selalu hidup bersama-sama untuk menyelesaikan masalah yang dihadapi. Para santri juga tidak acuh pada kebutuhan teman-temannya. Para santri selalu berbagi dan saling tolong menolong dalam keseharian.

Kendati pondok pesantren merupakan potret ideal pendidikan Islam dan pembelajaran agama Islam. Namun tampaknya, pemerintah masih enggan mengarus-utamakan sistem tersebut. Mereka cenderung memaksakan sistem pendidikan Barat, yang dalam anggapan para akademisi, lebih modern dan bisa dipertanggung jawabkan secara ilmiah. Oleh karena itulah, kontestasi diskursus sistem pendidikan nasional terus berjalan hingga sekarang; apakah dari sisi kelembagaan dan sistem pembelajaran. Akhir-akhir ini, pemerintah pun dibuat bimbang, kala lembaga pendidikan Islam dan pembelajaran agama Islam menjadi bagan integral dari proses sosialisasi ideologisasi Islamisme radikal. Pemerintah, imbas dari demokratisasi sistem pendidikan, tidak bisa mengontrol lembaga dan bahan ajar agama Islam yang diinternalisasikan di lembaga pendidikan umum.

Maka tidak mengherankan, apabila corak pendidikan Islam hari ini memiliki banyak wajah dan cenderung distigmatisasi berbeda-beda; ada yang dianggap sebagai penguat sikap nasionalisme dan sistem demokrasi di Indonesia. Ada anggapan pula pendidikan Islam menjadi corong dan induk radikalisme. Dan masih banyak corak antropologis lainnya. Padahal, kalau dilihat dari konsepsi di atas, serta fakta di lapangan, tidak satupun pondok pesantren menginginkan adanya perubahan ideologi keindonesiaan menjadi lebih islamis. Bagi para kyai-pesantren, Islam tidak harus dihadirkan sebagai sistem politik, melainkan menjadi ruh perpolitikan yang ada di Indonesia. Walaupun hari ini ada banyak pesantren yang ditengari menjadi simbol radikalisme, dapat dipastikan, pondok pesantren tersebut memiliki afiliasi dengan ideologi transnasional, serta ideologi yang diinjeksi secara transnasional. Sebut saja sebagai contohnya, PP. Ngruki, Solo, Jawa Tengah. ${ }^{18}$

Selain citera pendidikan Islam, pembelajaran Agama Islam di Sekolah Umum, juga tidak luput dari proses konstrusi sikap intoleransi terhadap perbedaan agama. Riset kolaboratif para akademisi di bawah naungan Maarif Institute dan Wahid Institute menunjukkan bahwa ada banyak guru yang tidak memahami aspek kebudayaan Islam di Indonesia, sehingga mereka cenderung memaksakan dan mengintimidasi corak keislaman murni menurut paradigma kelompok radikal. Ditambah lagi, kerangka berfikir guru disublimasi dalam bentuk budaya keislaman yang kuat, melalui organisasi siswa, dan kegiatan

${ }^{18}$ Charlene Tan, Islamic Education and Indoctrination, 187. 
ekstra kulikuler di luar sekolah. ${ }^{19}$ Kondisi inilah, yang menjadikan penulis ingin menunjukkan bahwa, pondok pesantren saja, yang nilai-nilai keislamaannya kental dan sangat otoritatif mengajarkan agama Islam, tetap menyisipkan sikapsikap toleran dan menghargai perbedaan yang terjadi di masyarakat. Para kyai dan guru di lingkungan pondok pesantren tidak memaksakan carapandangnya sebagai carapandang yang paling benar; khususnya, apabila harus berkaitan dengan keyakinan orang lain. Para kyai dan guru di lingkungan pesantren, membimbing para santri dalam corak keberagaman.

Tak jarang, di lingkungan pondok pesantren, mendengarkan slogan "perkataanku benar, dan bisa jadi, perkataan orang lain itu lebih benar". Atau perilaku yang ditampakkan para ulama' salaf. Contoh, ketika KH. Hasyim Asy'ari dan KH. M. Faqih Mas Kumambang memiliki perbedaan pandangan tentang bedug. Keduanya tidak pernah memaksanakan pandangannya yang paling benar. Mereka 'membiarkan' keyakinan masing-masing diikuti oleh pengikutnya, sekaligus meminta pengikutnya untuk saling menghormati. Ketika KH. Hasyim Asy'ari berkunjung ke Gresik, KH. Faqih Mas Kumambang menghormati KH. Hasyim Asy'ari, dengan membunyikan bedug di masjidnya. Demikian sebaliknya, ketika KH. M. Faqih Mas Kumambang berkunjung ke Tebuireng, KH. Hasyim Asy'ari meminta santri untuk tidak membunyikan bedug yang ada di masjid. ${ }^{20}$ Postulasi-postulasi sikap para kyai yang berbeda pandangan inilah yang akan penulis rangkai untuk menjadi satu kesatuan sistem kebudayaan pondok pesantren. Khususnya, di Pondok Pesantren Nurul Jadid, Paiton Probolinggo.

\section{Postulasi Toleransi dan Pluralitas Sikap Kiai PP. Nurul Jadid}

Pondok Pesantren Nurul Jadid sudah berumur 68 Tahun lamanya. Meski, secara kepemimpinan, masih berada pada generasi kedua, yakni diasuh oleh $\mathrm{KH}$. Zuhri Zaini, putera dari KH. Zaini Mun'im, pendiri sekaligus pengasuh pertama. Dalam perjalanan panjangnya, pondok pesantren Nurul Jadid, selanjutnya disingkat PP. Nurul Jadid, sudah banyak melakukan tranformasi, menyesuaikan dengan tuntutan dan kebutuhan masyarakat yang bersedia memondokkan anaknya di PP. Nurul Jadid. Kendati sudah dirubah, postur kebudayaan di PP. Nurul Jadid tidak pernah dirubah. Dalam pemaparan di dalam buku panduan santri, ada tiga nilai dasar dan panca (lima) kesadaran santri yang harus dipegang teguh. Tiga pilar dasar adalah berkomitmen untuk melakukan kewajiban individu (il ihtimam bi al furud al 'ainiyah), berkomitmen

\footnotetext{
${ }^{19}$ Andre Ata Ujan dkk, Multikulturalisme Belajar Hidup Bersama dalam Perbedaan (Jakarta: Indeks : 2011), 110.

${ }^{20}$ Lihat:http://www.nu.or.id/post/read/69419/ketika-kh-hasyim-asyari-turunkan-beduguntuk-hormati-tamu. Diakses pada 23 Maret 2017.
}

Jurnal Pendidikan Agama Islam (Journal of Islamic Education Studies)

Volume 5 Nomor 1 (2017)

ISSN(p) 2089-1946\& ISSN(e) 2527-4511

Hal. 10 - 20 
meninggalkan dosa-dosa besar (al ihtimam bi tarki al kabair, dan berbuat baik pada Allah dan dengan sesama (husnu al adab ma'a allah wa al khalq). Sedangkan ada pula lima kesadaran yang harus dibangun pada santri; mulai dari beragama, berilmu, bermasyarakat, berbangsa dan bernegara, dan terakhir berorganisasi. ${ }^{21}$

Trilogi dan panca kesadaran santri ini terimplementasi secara masif, baik di dalam lembaga pendidikan formal maupun non-formal yang berada di bawah naungan pondok pesantren. Di lembaga formal, penyampaian nilai tersebut lebih sistematis dan terukur, sedangkan di lembaga pemondokan sistemnya lebih tradisional. Artinya, masih melalui sistem sorogan, bandongan, dan halaqah, baik itu dipimpin langsung oleh para kyai ataupun pengurus yang diberi otoritas oleh para kyai. Selain diinternalisasi melalui pendekatan formal, para kyai dan tenaga pendidik di PP. Nurul Jadid juga menghadirkan nilai-nilai tersebut dalam wujud perilaku sehari-hari. Artinya, para santri bisa melihat secara tampak bagaimana sikap-sikap itu dilakukan oleh para kyai dan para guru, serta alumni PP. Nurul Jadid. Salah satu contoh riil-nya, adalah sikap politik-praktis para kyai PP. Nurul Jadid di beberapa suksesi kepemimpinan daerah atau nasional. Para kyai tidak pernah satu frame pilihan dan tidak juga memaksakan para santri untuk memilih apa yang menjadi pilihan kyai tersebut.

Namun, contoh di atas, hanya sebatas kilasan sikap yang tidak berhubungan dengan nilai keagamaan yang toleran. Berikut ini adalah beberapa contoh dan sikap toleran yang ditunjukkan PP. Nurul Jadid, spesifikanya berhubungan dengan perbedaan pandangan agama dan aliran keagamaan. Pertama, di tahun 2005, PP. Nurul Jadid mendapatkan musibah, kala salah seorang alumninya menjadi penganut dan pengurus sebuah Yayasan keagamaan, yang disinyalir sesat/menyimpang dari ajaran Islam. Sebagaimana pemaparan Abu Hasan Agus Rahmatullah, Kyai tidak mengambil sikap anarkhis terhadap perbedaan pandangan ini. Kyai memberikan instruksi kepada semua pengurus agar dapat membantu proses hukum yang berlaku, hingga proses pengembalian akidah alumni tersebut, apabila hal tersebut dimungkinkan untuk dilakukan. ${ }^{22}$ Kedua, tragedi pengusiran dan pembakaran komunitas Shi'ah di Sampang. Pada kasus ini, posisi PP. Nurul Jadid, memang tidak bersinggungan langsung. Tapi, harus diakui, komunitas Shi'ah di Jawa Timur tergolong besar dan berada di beberapa daerah; di Bondowoso, Pasuruan, dan Situbondo misalnya. Dalam konteks Shi'ah pun sama, para santri dan pengurus PP. Nurul Jadid, diharapkan untuk tidak ikut campur dalam persoalan teologis ini. Hal yang diserukan adalah menghargai perbedaan, sekaligus melakukan dialog-dialog intensif untuk

21 Panduan Wali Santri Pondok Pesantren Nurul Jadid Paiton Probolinggo atau akses web nuruljadid.net

22 Wawancara dengan Kaprodi PGRA Pada 23 Maret 2017. 
mencari jalan keluar kebersamaan antara mereka yang memiliki perbedaan pandangan. ${ }^{23}$

Itu semua adalah bentuk sikap dan keterikatan pondok pesantren dengan masyarakat sekitar. Di internal pondok pesantren sendiri, sikap toleran dan pluralistik pun disajikan dengan sangat gamblang. Misalnya, PP. Nurul Jadid, melalui lembaga pendidikan formal unggulnya tidak membedakan peserta didik yang berbeda agama, guru yang berbeda agama, serta para guru berbeda pandangan keagamaan. Di internal pula, para kyai tidak mendahulukan proses rekrutmen berbasis pada kealumnian, melainkan pada profesionalitas kerja dan kesesuaian latar yang dimiliki seseorang. Keterbukaan sikap ini terlihat sangat tampak bagi semua para santri. Serta dipahami sebagai bagian dari nilai-nilai yang terkandung di budaya PP. Nurul Jadid, Paiton.

Mursyid dalam penelitian menegaskan beberapa fakta menarik lain, bagaimana PP. Nurul Jadid memiliki carapandang dan sikap toleransi. Dia mengatakan bahwa berikut ini adalah bentuk-bentuk yang ada di PP. Nurul Jadid, Paiton,

"Keterbukaan untuk menerima tenaga pengajar. Sedikit mengulang data; di PP. Nurul Jadid sempat menerima volenteer yang berasal dari Australia, USA, dan China, yang agamanya berbeda-beda. Melakukan dialog-dialog/seminar dengan pemateri yang berbeda Agama. Ada ruang bagi penganut paham keagamaan dalam Islam yang beragam untuk menjadi tenaga pendidik di Pesantren Nurul Jadid, karena dalam system penerimaan tenaga pendidik tidak ada penelusuran latarbelakang paham keagamaannya. PP. Nurul Jadid seringkali melakukan kerjasama dengan lembaga lain, khususnya, yang berbeda agama. Baik dalam pendidikan, kesehatan, maupun ekonomi. Dalam menyikapi perbedaan pandangan di internal umat Islam, PP. Nurul Jadid, seringkali memilih jalan dialog." 24

Dari sini, bisa disimpulkan, PP. Nurul Jadid selain memiliki basis nilai kebudayaan yang jelas, mereka juga membentuk konstruksi kegiatan-kegiatan implementatif yang bisa dirasakan langsung oleh para santri sebagai pengejawantahan dari visi PP. Nurul Jadid. Penulis pun, sebagai bagian dari insider, secara observasional bisa merasakan bagaimana beragamnya tampilan sikap para kyai dalam menanggapi dinamika yang terjadi di luar pondok pesantren, sekaligus membingkainya dalam konteks kepesantrenan. Meskipun harus juga diakui, penguatan nilai-nilai toleransi dan penerimaan terhadap perbedaan, menjadikan santri PP. Nurul Jadid berada diambang kebimbingan

${ }^{23}$ Wawancara dengan Ketua Kepesantrenan Pada 23 Maret 2017.

24 Mursyid, "Strategi Pengembangan Nilai Toleransi dalam Pendidikan Pesantren (Studi Tindakan Sosial Dalam Menyikapi Pluralitas Agama Dan Paham Keagamaan di Pondok Pesantren Tebuireng Jombang dan Nurul Jadid Paiton Jawa Timur)" (Disertasi, Surabaya: PPS IAIN Sunan Ampel, 2007).

Jurnal Pendidikan Agama Islam (Journal of Islamic Education Studies)

Volume 5 Nomor 1 (2017)

ISSN(p) 2089-1946\& ISSN(e) 2527-4511

Hal. 12 - 20 
sikap Islamisme-Otentik. Artinya, ghirah untuk menguatkan nilai-nilai keislaman di masyarakat lebih minim, dibandingkan membangun paradigma masyarakat berbasis pada pemikiran-pemikiran yang progresif atau bisa dikatakan, lebih liberal dibandingkan fundamentalis.

\section{Konstruktivisme Sikap dan Aktivitas Budaya Toleran di PP. Nurul Jadid}

Salah satu karya konfrehensif bagaimana PP. Nurul Jadid membingkai nilai-nilai toleransi menjadi bentuk budaya kepesantrenan adalah penelitian Mursyid. Dalam risetnya, dia membingkai pondok pesantren Tebuireng, Jombang dan Pondok Pesantren Nurul Jadid, Paiton, sebagai contoh pendidikan pesantren yang toleran dan pluralis. Temuan dia, menyebutkan bahwa ada beberapa kekuatan utama pondok pesantren untuk membingkai sikap toleran: Pertama, inklusivisme dan paradigma sufistik kiai. Kedua, budaya pesantren yang terbiasa membaca fenomena dari pelbagai tinjauan referensi. Ketiga, adanya basis nilai dasar yang diinternalisasi. Keempat, adanya kekuatan dukungan para pengajar yang juga memiliki basis keilmuan serupa. ${ }^{25}$ Paradigma inklusivisme kyai hadir dari kematangan berfikir keagamaan. Bukan sekedar pemahaman sosiologiskultural. Dalam paparan datanya, dia menyebutkan pandangan KH. Zuhri Zaini tentang takdir keragamaan yang sengaja dibuat oleh Allah SWT agar manusia mampu menunjukkan sikap-sikap ketuhanan. Sikap-sikap yang menyayangi antar sesama manusia. Sikap-sikap yang tidak boleh menganggap bahwa pandangannya yang paling benar.

Adapun tradisi pesantren yang tidak hanya memiliki satu preferensi untuk menilai fenomena di luar pesantren, terbentuk dari paradigma kajian yang ada di pondok pesantren. Diakui atau tidak, pondok pesantren merupakan pasar dari semua madzhab, landasan pemikiran keislaman, hingga pada proses pertarungan ideologisasi keislaman. Tentu, kebiasaan pesantren mendiskusikan persoalan kekinian selalu dikontekskan pada cara berfikir yang berbasis pada kitab kuning dan pandangan ulama'-ulama' salaf. Namun, pada proses pelaksanaanya, para kyai umumnya, mencari format baru model penyampaian (dakwah) yang lebih elegan dan sesuai dengan bahasa-bahasa masyarakat sekitar. Para kyai, akan sangat sulit memahami diskursus toleransi yang dimaktub oleh akademisi. Tapi, mereka tahu bahwa subtansi dari toleransi adalah memahami perbedaan dan menghargai apapun yang terjadi di dalam masyarakat sebagai bentuk takdir ilahi yang tidak bisa diganggu gugat.

Selanjutnya, nilai-nilai dasar di PP. Nurul Jadid yang diinternalisasi melalui proses pembudayaan sikap menerima perbedaan dan perkembangan

25 Mursyid, "Strategi Pengembangan Nilai Toleransi dalam Pendidikan Pesantren". 
zaman. Dalam kurun sejarah yang panjang ini, PP. Nurul Jadid sudah memiliki keragaman proses internalisasi nilai yang sangat kuat berkaitan dengan nilai kebangsaan dan keindonesiaan. Para kyai di PP. Nurul Jadid tidak menjauhkan para santrinya dengan aktivitas kenegaraan. Para santri diwajibkan untuk mengikuti upacara kemerdekaan, berkumpul dengan lembaga-lembaga pendidikan formal lainnya di lapangan. Atau bahkan, mereka diundang untuk menghadiri upacara-upacara kenegaraan di lembaga pemerintahan. Hal ini penting untuk ditunjukkan. Pasalnya, salah satu faktor menguatkan radikalisme Islam dan intoleransi di lembaga pendidikan, diakibatkan oleh para peserta didik dijauhkan dari identitas asli Indonesia yang beragam. Di lembaga pendidikan tersebut, mereka cenderung dikenalkan dengan model keislaman yang satu frame dan ideologi tertentu.

Terakhir, Mursyid juga menegaskan pentingnya peran guru dan tenaga pengajar untuk melanjutkan cita-cita yang digariskan di dalam PP. Nurul Jadid. Dari data yang dipaparkannya, sudut pandang Kyai dan para guru bersinerji linier. Artinya, keberadaan KH. Zuhri Zaini yang memiliki kematangan intelektual dan spiritual, menjadikan para guru mengikutinya secara langsung. Sebagaimana teori Coleman, aktor individu menciptakan aktor korporat yang menjaga dan men-sustainable-kan nilai-nilai yang dipegang oleh aktor individu tersebut. Peran aktor korporat (baca; para guru) adalah menghadirkan paradigma Kyai yang inklusif dan toleran agar para santri mampu menterjemahkan perilaku santri dengan baik dan benar. Bagan berikut ini adalah kerangka umum bagaimana pendidikan toleransi di pesantren dipaparkan oleh Mursyid. Dia memberi nama temuannya, Piramida Pendidikan Toleransi Sunan Ampel.

\section{PIRAMIDA PENDIDIKAN TOLERANSI PONDOK PESANTREN}

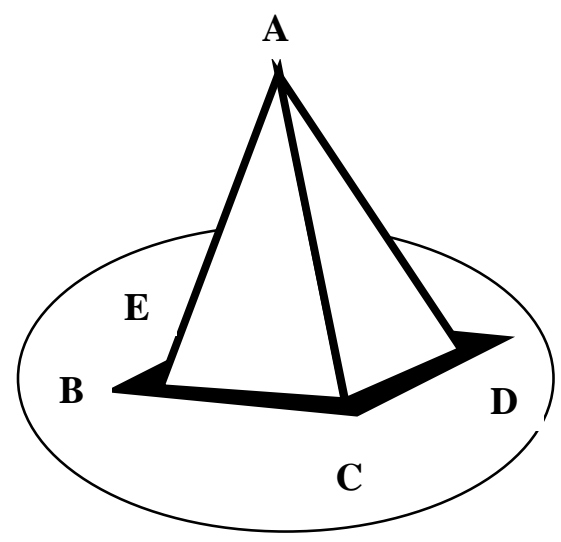

Jurnal Pendidikan Agama Islam (Journal of Islamic Education Studies)

Volume 5 Nomor 1 (2017)

ISSN(p) 2089-1946\& ISSN(e) 2527-4511

Hal. 14 - 20 
Keterangan gambar :

Puncak A

: Tujuan pendidikan toleransi, yaitu Santri Toleran.

Garis Bentang B-C

: Fondasi teologis, sebagai landasan fondasional pendidikan toleransi.

Garis Bentang C-E : : Fondasi etik, sebagai landasan fondasional pendidikan toleransi.

Garis bentang B-D

: Fondasi sosiologis, sebagai landasan fondasional pendidikan toleransi

Garis bentang D-E

: Fondasi ideologis, sebagai landasan fondasional

Garis tegak B-A pendidikan toleransi

Garis tegak C-A

Garis tegak D-A

: Pilar I, Kyai dan Tenaga Pendidik yang moderat, inklusif-pluralis

: Pilar II, Budaya damai dan toleran yang mensejarah

Garis tegak E-A

: Pilar III, Inklusifitas kelembagaan Pondok Pesantren

Bidang B-C-D-E

: Pilar IV, Relasi sosial Kyai-Santri

: Bidang eksoterisme-esoterisme dan inklusifisme-

Bidang A-B-C pluralisme, sebagai landasan Paradigmatik

: Moral modeling, tindakan toleransi dalam keteladanan kyai, sebagai tahapan pertama dalam strategi proses

Bidang A-C-D : : Moral habituation, pembiasaan hidup toleran dalam interaksi sosial lintas agama dan paham keagamaan dalam Islam, sebagai tahapan kedua dalam strategi proses

Bidang A-D-E $\quad$ : Moral feeling, tumbuhnya perasaan toleransi melalui penyerapan nilai toleransi oleh peserta didik dari proses moral action dan moral habituation, sebagai tahapan ketiga dalam strategi proses

Bidang A-B-E : Moral knowing, pengetahuan toleransi yang disajikan dalam pengarahan kyai, dan disampaikan secara integral dalam pembelajaran mata pelajaran/mata kuliah yang relevan, sebagai tahapan keempat yang menjadi langkah penunjang dalam strategi proses.

Lingkaran : : Ruang terwujudnya perilaku kolektif toleran.

Menurut pembacaan penulis, kerangka Piramida Pendidikan Toleransi ini bermuara pada tiga aspek; pertama, kyai dan guru yang inklusif. Kedua, budaya toleran yang ditampilkan (tolerance exibition) seperti yang sangat tampak di PP. Tebuireng Jombang, dimana Kyai dan para pengasuh yang lainnya memiliki andil membangun Indnonesia yang plural, seperti KH. Wahid Hasyim dan puteranya, 
KH. Abdurrahman Wahid. Sedangkan di PP. Nurul Jadid, para pengasuhnya tidak memiliki karakter menasional seperti yang ada di PP. Tebuireng Jombang, solusi yang dilakukan adalah menampakkan apa yang ada hari ini, khususnya dari kezuhudan dan ke-sufian KH. Zuhri Zaini. Ketiga, penanaman nilai-nilai yang sistematis dilakukan. Pada bagian ini, kedua lembaga ini memiliki problem serupa. Mereka tidak memiliki kurikulum yang spesifik terkait pola interaksi dan konstrutivisme di dunia pendidikan. Para santri dibiarkan 'liar' untuk memahami proses-proses yang sudah berjalan serta dijalankan oleh para pendiri dan pengasuh pondok pesantren tersebut.

Kerangka lain yang tidak bisa diakses adalah melakukan proses generalisasi pendidikan toleransi di luar lembaga pendidikan Islam (baca; pesantren). Di luar pesantren tidak memiliki role-model (Kyai) laiknya yang ada di pesantren. Oleh karena itu, diperlukan proses-proses pembaharuan untuk bisa menghadirkan pendidikan toleran berbasis pada nilai-nilai kepesantrenan ini sebagai basis utama sistem pendidikan nasional. Salah satu caranya adalah membingkai ulang desain pendidikan toleransi di luar, kemudian membawanya ke pengalaman-pengamalan yang basis nilainya ada di lembaga pesantren. Hal tersebut, dalam wujud implementasi, tentunya tidak sulit. Pasalnya, branding of full-day school dan building of Islamic Culture sudah menjadi primadona di kalangan masyarakat Indonesia, utamanya mereka yang berada di wilayah perkotaan.

\section{E. Torehan Desain: Generalisasi dalam Proses Pembelajaran}

Pada bagian ini adalah kerangka re-desain dari teori pendidikan toleransi dan indoktrinasi pemahaman pluralitas keagamaan di pondok pesantren, yang penulis anggap, bisa dikoneksikan dengan kerangka berfikir di lembaga pendidikan selain pesantren, melalui paradigma teoritik yang berbeda. Sebagaimana diketahui, kerangka berfikir teoritik yang dikembangkan oleh Mursyid di atas, berasaskan pada pilihan rasional James A. Coleman dan teori Integrasi mikro-makro George Ritzer. Keduanya digunakan Mursyid untuk membingkai bagaimana para Kyai dan tenaga pengajar di Pondok Pesantren mengejawantahkan nilai-nilai toleran yang termaktub di dua pondok pesantren tersebut. Oleh karena paradigma sosialnya masih berbasis pada ruang fenomenologisme, dan cenderung menghadirkan spacing yang terisolasi pada ruang kepesantrenan. Penulis beranggapan kerangka nilai tersebut bisa digeneralisasi melalui paradigma sosial yang lebih makro dan tidak terikat dengan isolated spacing yang ada. Maka dari itu, penulis akan mengganti kerangka teori tersebut berdasarkan pada konstruktivisme pendidikan toleran dan plural. 
Penulis menyadari kerangka konstruktivisme ini tidak berarti yang paling benar. Hanya saja, kerangka ini hadir sebagai pelengkap dari apa yang sebelumnya sudah digagas melalui lokus lembaga pendidikan khas Indonesia, yakni; pesantren. Sebelum menganalis berikut ini adalah beberapa konsepsi umum tentang teori konstruksi sosial Peter L. Berger. teori konstruksi sosial adalah teori sosial yang menganggap bahwa manusia dan masyarakat merupakan produk dialektis, dinamis, dan plural secara terus menerus. ${ }^{26}$ Teori ini meyakini bahwa ada tiga tahapan penting manusia dan masyarakat menciptakan kesadaran inividu atau kolektifnya. Pertama, eksternalisasi. Dimana manusia menuangkan semua gagasannya menjadi bagian dari realitas. Kedua, objektivasi, yaitu posisi, diman setelah mereka menyadari realitas-objektif, maka meyakini bahwa yang dilakukannya merupakan hal yang benar. Ketiga, internalisasi. Sebuah kesadaran untuk menciptakan sendiri, apapun yang sudah disadarinya sebagai pilihan individu atau kolektif. ${ }^{27}$

Pada intinya, P. L Berger ingin mengatakan bahwa realitas kehidupan individu berdialekti-aktif dengan komunitas, dan kemonitas bisa diciptakan melalui kesadaran yang kuat pada diri sendiri, termasuk di dalamnya adalah di ruang pendidikan. Salah satu contoh aplikatif teori ini dilakukan oleh Mike O'Donnell berjudul The Social Construction of Youthful Musculinities; Peer Group Sub-Culture. Penelitian ini dilakukan di beberpa sekolah di Inggris. Dalam penelitiannya, disebutkan bahwa ketika ada proses pergeseran perilaku laki-laki di beberapa negara maju dan adanya perbedaan persepsi tentang sifat-sifat lakilaki, dari berbagai perbedaan ras dan kultur, maka diperlukan adanya konstruksi baru terkait dengan nilai-nilai kelakian untuk membangun sebuah paradigma yang sama, apakah itu di dalam lembaga pendidikan ataupun diluar lembaga pendidikan. Salah satu cara paling efektif, menurut dia, dengan cara menciptakan kelompok pemuda yang bisa dicontoh dan dilihat oleh mereka yang memiliki perbedaan persepsi tersebut. ${ }^{28}$

Gagasan teori konstruksi sosial dan pendekatan metodik yang bisa dilakukan di atas, dapat digunakan untuk memindahkan nilai-nilai yang ada di lembaga pendidikan Islam pesantren, ke ruang lembaga pendidikan umum. Pastinya, proses pemindahan ini tidak bisa dilakukan secara holistik. Proses integrasi berbasis moving cultures and social-construction selalu berkaitan dengan komponen internal yang dimiliki; apakah itu nilai, aktor, komunitas, dan

${ }^{26}$ Peter L Berger, The Sacred Canopy; Elements of a Sociological Theory of Religion (New York; Anchor Books, 1967), 180.

27 Ibid., 182.

28 Mike O'Donnell , “The Social Construction Of Youthful Musculinities” dalam Stephen Ball The Routledge Falmer Reader of Sociology of Education ( New York; Routledge Falmer, 2004), 90. 
regulasi yang mengatur lembaga atau institusi tersebut. Dalam konteks lembaga pendidikan formal di Indonesia, nilai toleransi dan pluralitas keberagamaan sudah merupakan realitas objektif yang tidak bisa diganggu gugat. Sebuah realitas yang terinternalisasi di kalangan pemuda semenjak mereka berkumpul dan memahami dinamika sosial di masyarakat. Hanya saja, mereka membutuhkan tahapan terakhir dari kerangka yang dibangun oleh Peter $\mathrm{L}$ Berger yakni, internalisasi.

Proses internalisasi tersebut, bagi Berger, tidak sekedar proses 'efek' dan 'refleksi' semata, melainkan proses kontinuitas dan sutainsibilitas untuk proses menjadi masyarakat dan manusia. Oleh karenanya, internalisasi nilai pendidikan toleran dan pluralis - yang setidaknya dijalankan di dalam pesantren melalui habituasi sikap dan kegiatan-kegiatan yang berkelanjutan - juga bisa dijalankan dengan cara seksama. Maksudnya, para kepala sekolah, guru, dan civitas akademik di dalam lembaga pendidikan harus memiliki komitment bersama untuk menjalankan nilai-nilai pluralitas dan toleransi dalam kehidupan nyata. Sedang bagi siswa dan peserta didik, mereka hanya memerlukan re-enforcment pemahaman (ngilmune amal) yang sudah dijelaskan melalui mata pelajaran Pendidikan Kewarganegaraan atau keagamaan yang ada di lembaga pendidikan formal. Terakhir, sebagaimana sudah disebutkan sebelum-sebelumnya, peran guru yang berinteraksi langsung dengan para siswa harus juga berseragam untuk mendengungkan sikap toleran dan pluralis di dalam kehidupan seharihari.

\section{F. Penutup}

Betapapun rancang bangun pondok pesantren di Indonesia tidak akan pernah lepas dari nilai-nilai toleransi dan kesadaran takdiri bahwa nusantara dibangun dari keragaman. Nusantara dibentuk dari perbedaan-perbedaan yang berkembang tanpa proses diminta. Oleh karena itulah, memotret pendidikan pondok pesantren, sebagai lembaga yang toleran dan memiliki sikap pluralis, tidaklah sulit. Pesantren memiliki nilai dan budaya yang beragam. Punya aktor sosial yang memiliki kematangan intelektual dan spiritual secara bersamaan. Punya kedekatan dengan masyarakat, melalui cara menyapa (dakwah) yang khas. Pesantren juga punya, sistem pendidikan dan indoktrinasi yang lintas batasan waktu. Para pengabdi di pesantren memiliki keyakinan hidup bahwa keberkahan dan kemanfaatan ilmu lebih penting, dibandingkan seberapa banyak ilmu yang didapatkan.

Oleh sebab pendidikan pesantren merupakan miniatur Indonesia yang beragam, memindahkan nilai-nilai keislaman pesantren yang toleran dan plural, pun tidaklah sulit. Hal yang dibutuhkan adalah melakukan konstruksi sosial, 
membingkai nilai, dan memantapkan regulasi serta komitmen bersama, untuk menciptakan lembaga pendidikan Islam yang toleran dan plural. Lebih-lebih, lembaga pendidikan di luar pondok pesantren memiliki kekuatan (internal/eksternal); apakah itu Sumber Daya Manusia ataupun Sumber Daya Alam, yang dapat mendukung dan menguatkan apapun yang sudah dicanangkan oleh lembaga pendidikan formal. Pada akhirnya, apapun gagasan yang penulis tuangkan di atas, merupakan proses postulasi bahwa pesantren sangat toleran dalam mengahadapi masalah masyarakat, serta pesantren memiliki keunikan pendekatan untuk mereproduksi generasi muda yang toleran dan plural.

\section{G. Referensi}

Asrohah, Hanun. Transformasi Pesantren Pelembagaan Adaptasi, dan Respon Pesantren Dalam Menghadapi Perubahan Sosial. Jakarta: Dwiputra Pustaka Jaya, 2013.

Azra, Azzumardi. Pendidikan Islam; Tradisi dan Modernisasi di Tengah Tantangan Millenium III. Jakarta: UIN Jakarta Press, 2012.

Bawani, Imam. Tradisionalisme dalam Pendidikan Islam. Surabaya: Al Ikhlas, 1993.

Berger, Peter L. The Sacred Canopy; Elements of a Sociological Theory of Religion. New York; Anchor Books, 1967.

Bruisennen, Martin Van. "Tradisional and Islamist Pesantrens in Contemporary Indonesia" dalam Fasrish A Noor ed. Madrasa in Asia; Political Activism and Transnational Linkages. Amsterdam; Amsterdam University Press, 2008).

Esposito, J. The Future Of Islam. New York: Routledge, 2003.

Fealy, Greg., dan Bubablo. Jejak Kafilah, terj Akh. Muzaki. Bandung; Mizan, 2001.

Hefner, Robert W. Making Modern islam Politic of Education in South Asia. USA: Hawai University Press, 2009.

Holilurrahman. "Reintegrasi Ilmu, Agama, Agen, dan Fondasi Pendidikan Islam (Telaah Pemikiran KH. Hasyim Muzadi)" dalam Jurnal Kependidikan Islam Vol 1 Edisi 3.

Madjid, Nurcholish. Bilik-Bilik Pesantren. Jakarta: Dian Rakyat-Paramadina, tt.

Mas'ud, Abdurrahman. Memahami Agama Damai Dunia Pesantren, dalam Badrus Sholeh (Ed), Budaya Damai Komunitas Pesantren. Jakarta: LP3ES, 2007.

Moesa, Ali Machsan. Nasionalisme Kiai. Yogjakarta; LKiS, 2005.

Mursyid. "Strategi Pengembangan Nilai Toleransi dalam Pendidikan Pesantren (Studi Tindakan Sosial Dalam Menyikapi Pluralitas Agama Dan Paham 
Keagamaan di Pondok Pesantren Tebuireng Jombang dan Nurul Jadid Paiton Jawa Timur)". Disertasi, Surabaya: PPS IAIN Sunan Ampel, 2007.

O'Donnell, Mike. "The Social Construction Of Youthful Musculinities" dalam Stephen Ball The Routledge Falmer Reader of Sociology of Education. New York; Routledge Falmer, 2004.

Rahardjo, Dawam. Pesantren dan Pembaharuan. Jakarta: LP3ES, 1985.

Soebahar, Abdul Halim. Kebijakan Pendidikan Islam dan Poblematika Kekinian. Makalah Stadium General Program S3 IAIN Jember 2017.

Tan, Charlene. Islamic Education and Indoctrination; The Cases In Indonesia. New York, Routledge, 2011.

TM, Fuaduddin. "Diversifikasi Pendidikan Pesantren : Tantangan dan Solusi", dalam Jurnal Penelitian Pendidikan Agama dan Keagamaan, Volume 5 Nomor 4, Oktober - Desember 2007.

Ujan, Andre Ata. Multikulturalisme Belajar Hidup Bersama dalam Perbedaan. Jakarta: Indeks : 2011.

Wahid, Abdurrahman. "Pesantren Sebagai Sub-Culture Pendidikan di Indonesia" dalam M. Dawam Rahardjo (ed), Pergulatan Dunia Pesantren, Membangun dari Bawah. Jakarta: P3M, 1985.

Wahid, Abdurrahman. Pondok Pesantren Masa depan, dalam Said Agil Siraj at all, Pesantren Masa Depan Wacana Pemberdayaan dan Transformasi Pesantren. Bandung: Pustaka Hidayah, 1999.

http://www.nu.or.id/post/read/69419/ketika-kh-hasyim-asyari-turunkanbedug-untuk-hormati-tamu. 